\title{
Toward conservational anthropology: addressing anthropocentric bias in anthropology
}

\author{
Helen Kopnina
}

Published online: 30 March 2012

(C) The Author(s) 2012. This article is published with open access at Springerlink.com

\begin{abstract}
Anthropological literature addressing conservation and development often blames 'conservationists' as being neo-imperialist in their attempts to institute limits to commercial activities by imposing their post-materialist eco-ideology. The author argues that this view of conservationists is ironic in light of the fact that the very notion of 'development' is arguably an imposition of the (Western) elites. The anthropocentric bias in anthropology also permeates constructivist ethnographies of human-animal 'interactions,' which tend to emphasize the socio-cultural complexity and interconnectivity rather than the unequal and often extractive nature of this 'interaction.' Anthropocentrism is argued to be counteractive to reconciling conservationists' efforts at environmental protection with the traditional ontologies of the interdependency of human-nature relationship.
\end{abstract}

Keywords Anthropocentrism · Applied anthropology · Conservation · Constructivism · Development · Conservation/culture conflict $\cdot$ Eco-centrism

\section{Introduction}

Participation of the local communities in (or against) conservation became an important subject of anthropological inquiry (Trusty 2011). Participation is nowhere more hotly debated than in the areas of conservation and development, where the requirements of ecological sustainability often collide with the demands of indigenous people seeking to control their own natural resources (e.g., Walker et al. 2007). A few areas of anthropological interest can be outlined in relation to the subjects of conservation and development.

\footnotetext{
H. Kopnina ( $\square)$

University of Amsterdam, Amsterdam, The Netherlands

e-mail: alenka1973@yahoo.com
} 
The first line of inquiry investigates how the representatives of donors, states, and non-governmental organizations (NGOs) create and assert moral narratives, and what strategies they use to negotiate competing moral narratives (e.g., Orlove and Brush 1996; Zerner 2003; West 2006; Shoreman-Quimet and Kopnina 2011). Conservation/development in the work of applied anthropologists outlines a number of countercurrents of grassroots efforts to achieve conservation with social justice (West 2006; Nelson 2012).

Connected to these countercurrents, the second line of inquiry examines the connection between moral narratives and implementing activities. The moral engagement of anthropologists is often associated with the position of the local people, indigenous communities, and minority or marginalized groups in opposition to the political and corporate elites funding development projects (Lewis 2005; Mosse 2005). Since these projects are designed and/or funded by outsiders, the donors, the state agencies, and the NGOs, anthropologists often pointed out that the extent of authority "handed over" to the people who are targeted by these projects is limited (e.g., Blaser et al. 2004; Haenn 2011; Trusty 2011).

The third line of inquiry focuses on the local communities affected by conservation and development governance and the ways in which they may challenge such governance or may participate in and reproduce its processes (e.g., Ellen 1993; Brosius 1997; McElroy 2013). This line of inquiry aims to analyze the instances of extensive dialogue between project designers and local people, including grassroots initiatives. This line of inquiry includes the politics of conservation (e.g., Gururani 1995, 2000; Chernela 2001; Ellen 2008), livelihood strategies and local perceptions (e.g., Parkes 2000; Lowe 2005), indigenous knowledge and biodiversity (e.g., Gadgil 1993; Muller-Böker 2000; Posey and Balick 2006), and conflicting ontologies of biodiversity conservation and resource management (e.g., Novellino 2009; West 2005; Trusty 2011).

A final line of inquiry reflects upon the moral positionality and responsibility of anthropologists (e.g., Mead 1977; Lewis 2005; Horowitz 2010). The author proposes to expand this line of inquiry to address the positioning of anthropologists in relation to conservationists and the non-human subjects they represent. The author will first examine two sub-fields in anthropology concerned with culture and conservation-the so-called applied anthropology supporting development, and constructivism, with its focus on social construction of 'nature' and non-human species. Consequently, eco-centrism theory will be examined in relation to these two sub-fields of anthropology. In conclusion, the author will examine the implications of anthropological ethical positioning for conservation.

\section{Applied anthropology and development}

While Bronislaw Malinowski advocated a role for applied anthropologists as policy advisors to colonial administrators, Evans Pritchard argued that anthropologists should distance themselves from the tainted worlds of 'applied involvement' (Lewis 2005). In her essay 'Applied Anthropology: The State of the Art,' Margaret Mead (1977) reviewed the history of anthropology as largely embracing applied public 
service work. Observing the increasing specialization and expertise of anthropologists, Mead urged her colleagues to reestablish a disciplinary commitment to public anthropology, especially government service. John Bodley (2008) on the other hand argued that anthropologists siding with government service and development agencies are choosing the wrong side.

Anthropological relationship with the subject of 'development' and their own positioning through development agencies and indigenous people remains ambiguous (Mosse 2005; Lewis and Mosse 2006). Some consider development agencies as creators of 'monocultures of the mind' (Shiva 1993) in which the new 'holy grail' of the dominant political elites, the consumerist culture, is perpetuated, and native ways of relating to each other as well as to plants and animals are undermined (Black 2010). In examining the relationship between economic and technological progress and the health and welfare of local communities, Bodley (2008) argues that increased consumption, lowered mortality, and the eradication of all traditional controls have combined to replace what for most tribal peoples was a relatively stable balance between population and natural resources, with a new system that is imbalanced. Reflecting on the relativity of the very concepts of 'progress' and 'quality of life,' many anthropologists question the 'goodness' of industrialization and the whole enterprise of 'development,' including the 'democratic sharing' of the green revolution, medical technologies, and other 'seductive blessings' (Diamond 1987).

In stark contrast to development anthropologists employed by organizations such as IMF and the World Bank who may be sympathetic to the ideas of 'development,' many environmental anthropologists are wary of these seductive blessings when these are imposed on local populations (Tsing 1999). The wisdom of the Native tribes in the face of development is emphasized by the quote attributed to the Native American Cree tribe: "When all the trees have been cut down, when all the animals have been hunted, when all the waters are polluted, when all the air is unsafe to breathe, only then will you discover you cannot eat money." Indeed, in this endlessly complicated time of growing economic need and environmental deterioration, the internalization of the ideas of 'progress,' as well as the seemingly global acceptance of wage labor and consumerism (in which 'native' populations contribute to the further degradation of their own culture and environment), poses new ethical challenges for the increasingly 'engaged' anthropologists.

\section{Development and conservation: anthropological criticism}

Some anthropologists consider conservationist organizations as part of the development enterprise extending their neo-colonial, imperialist legacy to areas of traditional practices such as hunting (e.g., Einarsson 1993; Escobar 1996). They argue that preservation areas and restrictions undermine traditional housing patterns and subsistence of indigenous communities (e.g., Brockington 2002). On the other hand, pro-development anthropologists see conservation organizations as working 'against' human development in trying to limit the access of the 'dispossessed' to the spoils of modern industrial societies and deny the indigenous people of the 
opportunity to profit from exploitation of natural resources (e.g., Sikor and Stahl 2011). These anthropologists often help development agencies to achieve the goals of poverty reduction, social equality, human rights, and indigenous rights, particularly in regard to claims on natural resources (Lewis 2005), and to use the World Bank terminology, ecosystem services.

An applied anthropologist, Alcorn blames conservation organizations for violating human rights:

The lands of Beauty overlap with poverty and corruption. And they overlap with the territory of a Beast that has increasing dominion to determine the life or death of Beauty. The 'Beast' is an unexpected one-public and private conservation agencies - a surprise for most people who believe conservation agencies unquestionably represent the defense of Beauty. Yet biodiversity conservation is increasingly viewed as 'ecofascism' by the culturally-diverse communities who coexist with biodiversity.

Why? Over 130 million culturally-diverse people have become 'conservation refugees' after being forcibly removed from their traditional relationship with the earth, in order to create parks, certified logging concessions, or concession areas for ecological service payments that directly benefit conservation agencies. These and other human rights violations have created deep conflict and suffering from the loss of both spiritual and material resources (Alcorn 2008:1).

The anthropological discussion group "Just Conservation" on Facebook serves to "To air grievances, concerns or experiences of conservation-related human rights abuses." According to Wenzel (1991), environmentalists in general, and animal rights activists in particular, are ethnocentric (or eco-centric, or Western-centric) cultural imperialists.

There are instances of anthropologists taking sides against conservationists in animal-human rights conflicts in the cause of guaranteeing local people their rights (e.g., Theodossopoulos 2002; Hartmann 2011). Interpretation of 'rights' may be conceived very broadly and often includes issues of social justice in distribution of 'natural resources' and indigenous land claims (Novellino 2003; Nelson 2012). Anthropologists may side in these cases with local authorities, Western aid and development workers, as well as groups that profit from these 'rights' the most, such as Japanese pro-whaling protagonists who "consciously attempt to hook up with discourses on 'Western' eco-imperialism, as the unjust universalizing of a particular nature-culture" (Blok 2010:21).

\section{The question of agency}

Who is seen by whom to hurt the environment the most? One school of thought in anthropology views the indigenous communities within 'traditional' and increasingly 'transitional' societies' as the kind of 'noble savages' living 'in harmony with nature.' In this view, it is (Western) political and economic elites who are largely responsible for the environmental problems. Caldwell (1990) and Chokor (1993), 
for example, suggest that indigenous, non-industrialized societies tend to believe in the profound connection between humanity and nature. Anthropologists provide examples of indigenous people who are the best forest protectors, finding compatibility between natural balance and the needs of humans in using natural resources (e.g., Posey and Balick 2006; Pearce 2012).

However, those who praise indigenous stewardship often forget to take deeply entrenched effects of economic globalization into account. Critics discredit this 'noble savage' depiction of tribal peoples who live in harmony with nature, asserting instead that indigenous peoples have 'human vices just as we do' (Wagley 1976:302). Indigenous people may view animals and plants as something not worth protecting (Allendorf et al. 2006; Infield 1988a), and are capable of overuse and poor decision-making (Netting 1993). There are also examples of indigenous peoples who claim land rights only to grant large timber cutting or mining concessions on their lands (e.g., Turner 1993). It appears that the majority of traits that once enabled traditional societies to live in greater harmony with the environment than more industrialized groups are slowly diminishing (Brosius 1999), and market pressures are driving the 'traditional stewards of nature' into unsustainable practices.

In Asia and Africa, local people frequently view wildlife from protected areas as pests (Infield 1988b; Newmark et al. 1993; Grundy 1995; Infield and Namara 2001; Allendorf et al. 2006; Trusty 2011), something to be feared (Infield 1988a; Allendorf 2007), or as valued by the government more than they value the local people (Brockington 2002; Igoe 2004).

Anthropologists have noted that the idea that the ecologically important economic activities are those which put people and the environment in immediate proximity is also salient to conservation research, especially to research on development projects that attempt to change the way people interact with their surroundings (Haenn 2011). However, conservational anthropology takes a step further to argue that the most ecologically important activity in the case of, for example, endangered species is to protect them-and urgently_against any human activity that would threaten their survival. This is not to say that the conservationists think that the poor people should be left 'to die rather than hunt' if their very physical survival is at stake. It must be noted that most of conservation/culture conflicts do not include famishing humans, but people who struggle for economic or social advantage. In other words, that the issue of non-human survival is normally not equally balanced with the issue of human welfare.

It seems thus that at the time of unprecedented threat to biodiversity, and rapid extinction of plant and animal species, anthropologists could work together with conservationists to ensure both cultural integrity and preservation of traditional practices and the survival of non-human species. Anthropologists supporting development seem to be oblivious to the fact that historical change from the time when human activities were not affecting the survival of the entire biosphere, and that a lot of what used to be traditional practice, such as hunting, has evolved into commercial activity. 
The essential problem is the unavoidable fact that an expanding economic system is placing additional burdens on a fixed earth system to the point of planetary overload ... Business as usual projections point to a state in which the ecological footprint of humanity will be equivalent to the regenerative capacity of two planets by 2030 (Foster et al. 2010).

Anthropologists, who claim to be particularly sensitive to context in which sociocultural changes occur, fail to notice that the transition to the capitalist economy have a much more profound negative influence on non-human species and human welfare in a larger ecological context than ever before (McElroy 2013).

\section{Anthropocentrism in constructivist view}

Yet another source of anthropocentric bias in anthropology is presented by the constructivist stream within the post-modern theory. Some constructionist anthropologists consider the concept of nature as a socially constructed entity, created by the 'actors,' and largely a product of language; a dependent construct connected to the human perception of it (e.g., Smith 1996; Walley 2004). 'Ecology' is mostly discussed in symbolic, historical, and political terms, overriding the dichotomies that informed and enlivened the debates of the past-nature/culture, idealism/ materialism - and informed by the literature on transnationalist flows and localglobal articulations (Biersack 1999), with the physical aspect of ecology conspicuously absent.

From this perspective, nature is not only represented by language but created by it, and ultimately becomes little more than an offshoot of social reality (Kidner 2000:264). This makes it impossible to judge one attitude toward nature as better or worse, more beneficial or more harmful than any other for, according to this logic, there is no nature outside the human perception of it (ibid). Nature as "an artifact, understood and interacted with by people via culturally specific symbolic systems" (Kang 2003:335) implies that there is no 'nature' outside of human perception of it. Thus from the constructionist viewpoint, to paraphrase David Hume's famous dictum, "if the tree falls in the forest but nobody hears the sound," the tree has not really fallen.

A group of anthropologists adhering to the Actor Network Theory (ANT) derived from studies of the social construction of science and technology by Callon (1986), Latour (1988), and Law (1986) postulate that society and nature are not divisible into easily identifiable compartments, but rather to different kinds of material forms (material heterogeneity), such as humans, machines, devices, and other living organisms. Co-constitutive relationships between people and non-humans embody the form, character, and content of human activities and the world which are intimately interdependent-resonating with Latour's 'experimental metaphysics,' which is intended to achieve the 'progressive composition' of people and their worlds (Healy 2007). In drawing on ANT, the ethnography of kangaroo products trade by Lorraine Thorne reveals the connections between spaces of calculation and spaces of killing often overlooked and dismissed as unconnected with human lives. 
A number of noteworthy non-anthropocentric ethnographies emerged out of ANT tradition.

The contemporary international trade in kangaroo products is an historically specific, complex set of (attenuated) relationships between hidden spaces, sites, and actors. Spatial metaphors help legitimate the kangaroo industry; in particular, deployment of spatial imaginaries has tangible, material impact upon the animals' lives. The taxonomy of abundance fuels public acceptance of kangaroo slaughter, underpinned by widespread popular images of 'virtual' kangaroo hordes bounding across a flat, virtual landscape. Ultimately, by casting kangaroos as large, abundant 'pests' now repackaged to serve the lucrative caused celèbre of biodiversity, the kangaroo trading network profoundly delimits the options for agency of the commercially targeted species. Kangaroo slaughter is thus rendered justifiable - a non-issue (Thorne 1998:168).

In their ethnography of otter preservation efforts, Goedeke and Rikoon (2008) use scientific controversy emerging from a river otter restoration project in Missouri to explore the role of nonhuman actors in the dynamism of networks forming to establish the ideals and outcomes of ecological restoration. The authors demonstrated how an epistemic controversy, sparked by the failure of authoritative spokespersons (such as scientists) to enroll river otters, fish, and waterways, opened the door for a more diverse group of spokespersons who, in turn, enrolled more actors to settle the controversy and emphasize the need to recognize the role of nonhumans as catalysts and actors because of their potential to challenge and change networks.

In Kohn's article, the author considers the challenges involved in knowing and interacting with other species and the implications this has for the practice of anthropology (Kohn 2007). He argues for the development of an anthropology that is not just confined to the human but is concerned with the effects of our "entanglements" (Raffles 2002) with other kinds of living selves. According to Ingold, "despite human attempts to hard surface this world, and to block the intermingling of substance and medium that is essential to growth and habitation, the creeping entanglements of life will always and eventually gain the upper hand" (Ingold 2008: 1796). Ethnographies exploring emotional connection with nature (Sobel 1996; Milton 2002) and continuing the work in human geography (Whatmore 2002; Castree 2003; Braun 2008) may provide the way forward from the anthropocentric paradigm.

Ethnographies of human-animal 'interactions,' such as those with dingo's (Healy, 2007), crocodiles (McGregor 2005), elephants (Thompson 2002; Barua 2010), whales (Einarsson 1993; Anders 2010; Blok 2010), and turtles (Theodossopoulos 1997) to name just a few, tend to emphasize the socio-cultural and political complexity and interdependency of (human) actors' networks, systems approach, action network theories. The stream of the so-called more-than-human geographies has mostly emphasized affirmative ways of interacting with other species and conceiving them through the cultural lens. The strength of these accounts has been to model the complex interconnectivity of humans and non-humans in shaping our world (Whatmore and Hinchliffe 2010). With some exceptions (Thorne 1998; Yussof 2011; Desmond 2011), 
most accounts have concentrated on presence, accommodation, and conviviality in human-animal relationships (Hinchliffe and Whatmore 2006) rather than the unequal and often extractive nature of this 'interaction.'

Panel organizers for the RGS-IBG Conference sponsored by Social and Cultural Geography Research Group in Edinburgh planned for July 2012, "More-than-human geographies: from coexistence to conflict and killing" called for papers exploring problematic relations that link human, animal and plant life on earth. The session aims to move beyond these conceptualizations by exploring more problematic relations that link human, animal, and plant life on earth and explore what has led anthropologists to shy away from more explicit engagements with conflict and killing. The conveners invite papers that focus on failure, break-down, powerlessness, asymmetry, non-relation, conflict, or killing in more-than-human geographies.

Obviously, conservationist work cannot be understood without realization of complexity of human agency and power. Yet the remarkable omission in this discussion are the implications of human-animal conflict for the (very existence) of non-human actors (Zerner 2000; Eckersley 2004). Anthropologists seem to be preoccupied with the symbolic creation of environments (Zerner 2003), social construction of 'nature' (Escobar 1996; Smith 1996), or 'wilderness' (Cronon 1996; Neumann 1998; Whatmore and Thorne 1998) and by implication 'environmental problems.' Conservational anthropology calls toward conscious realization that extinction of species is not just socially constructed but needs to be ethically addressed, the way the more traditional anthropological subjects, the local, the indigenous, the minority, the poor have been addressed. Conservational anthropology is a conscious, ethical, political, and practical call to include the rights of non-human actors in the discussion of environmental justice.

While it is not the purpose of this article to seek evidence to support or refute anthropological accusations, the author argues that the view of environmentalists as imposing neo-imperialist ideology is ironic in the view of the fact that the very notion of 'human rights' and 'development' (with accompanying non-traditional practices of, for example, the ownership of land, commercial use of 'natural resources,' as well as wage labor) are also Western concepts and impositions. It may be argued that stripped of ideological and ethical underpinnings, the argument of anti-environmental academics in favor of defending human rather than environmental rights is just as subjective, whether or not the 'native' people themselves are 'traditionally' pro-environmental. The author acknowledges the fact that she is not morally neutral in this position. As many other applied or engaged anthropologists who want their work to 'matter' in the world outside of academia, the author argues for the need of anthropological arbitration in order to address far-from-theoretical issues associated with conservation/culture conflict.

\section{Anthropocentric bias in anthropology}

Environmental sociologists seem to be ahead of their anthropological colleagues in asserting that social sciences, irrespective of their theoretical orientation, are prone to anthropocentric bias (Dunlap and Catton 1994). Environmental problems are not just socially constructed, and that the dangers posed to the environment, while seen 
through the socio-cultural lens, call for effective and perhaps innovative ways of addressing environmental problems, both by the local communities and by the anthropologists themselves (Kopnina and Shoreman-Ouimet 2011). However, while environmental anthropologists attempt to neither credit nor blame the indigenous communities or those 'in power' (political and economic elites) implicated in environmental protection or damage, many ethnographies still describe humanenvironment relationship from a utilitarian perspective and favor 'cultural survival' of the indigenous communities over the physical survival of other species. Preoccupation with environmental justice and socio-economic fairness, which is typical of 'sustainable development' discourse, is often much more pronounced in anthropological work than concern with biospheric egalitarianism, in which not only loss in human life and welfare, but also the consequences of human activity for nonhuman species and plants should be the basis of political action (Lidskog and Elander 2009:34). What can explain such an anthropocentric bias in anthropology?

William Catton and Riley Dunlap wrote a series of articles defined environmental sociology (Catton and Dunlap 1978a, 1978b, 1980; Dunlap and Catton 1979, 1983). Traditional sociology emerged out of the Dominant Western Worldview (DWW) defined by anthropocentrism and hence shared a set of related background assumptions, the Human Exceptionalism Paradigm (HEP), based on a shared anthropocentrism that led sociologists to treat modern societies as 'exempt' from ecological constraints. They accounted for the oversight by examining the taken-for-granted assumptions of mainstream sociology and explained how those assumptions led the discipline to ignore the environment outside them. Up to now, little re-evaluation of anthropocentric assumptions has taken place in the field of environmental anthropology.

Shoreman-Quimet and Kopnina (2011) critically examine the anthropological bias toward 'defending the natives'. Anthropological focus on the human rights issues is often pitched against the efforts of conservationist organizations and governments to institute limits to both the 'traditional way of life' which is increasingly intertwined with commercial interests of both the power holders and members of indigenous communities themselves (Walley 2002). These include hunting and fishingsometimes endangered-species, or (illegal) logging. While some anthropologist draw a clear line between poachers and squatters and local populations (Hughes 2005), the distinction between those who engage in ecologically destructive activities as 'criminals,' or in order to commercially profit from natural resources or as a matter of necessity and basic subsistence, is empirically complex. Simultaneously with the anthropological quest to preserve indigenous cultural practices, many anthropologists have expressed their critique toward environmentalists-particularly conservationists involved in the protection of non-human species.

Anthropocentric bias in anthropology is evident in the following quotation in the article published in the American Anthropologist by Conrad Kottak:

Biodiversity conservation has become an issue in political ecology, one of the subfields of the new ecological anthropology. Such conservation schemes may expose very different notions about the 'rights' and value of plants and animals versus those of humans. In Madagascar, many intellectuals and officials are bothered that foreigners seem more concerned about lemurs and other 
endangered species than about Madagascar's people. As one colleague there remarked, "The next time you come to Madagascar, there'll be no more Malagasy. All the people will have starved to death, and a lemur will have to meet you at the airport." Most Malagasy perceive human poverty as a more pressing problem than animal and plant survival (Kottak 1999:33).

Einarsson describes the mink whalers' struggle to earn their living despite environmentalists' efforts and reflects that there is a "serious need to show respect for the values and interests of local people relating to natural resources" (Einarsson 1993:82). Einarsson acknowledges that 'many anthropologists are suffering from "species compassion fatigue when they see this threatening to the way of life of people whom they have lived among and learned to appreciate" (Einarsson 1993:80).

\section{Explanations of anthropocentrism}

Within environmental ethics, there is a debate of whether non-human species should have intrinsic value or only instrumental value (Singer 1975; Regan 1984; Taylor 1986; Ferry 1995; DesJardins 2005). While development discourse maintains an instrumental and anthropocentric worldview and excludes the consideration of an eco-centric or bio-centric perspective (Spring 2004), conservationists tend to value nature intrinsically. The efforts of social focus charities in fostering human health and welfare may have indivertibly undermined the conservationists' concerns about the growth of human populations and the levels of consumption associated with biodiversity loss, leading to the 'charity paradox' (Kopnina and Keune 2010; Kopnina 2012).

Anthropologists supporting the development have often only considered animals and plants as the resource to be equally distributed and consumed and rarely recognized the intrinsic value and rights of non-human species (Noske 1989). While human rights, indigenous rights, gender, and race equality are taken for granted by anthropologists coming from traditions as diverse as eco-feminists, eco-Marxists, or eco-socialists, the eco-centric position is often ignored. Foster (2011) reflected that eco-anarchists have been better than eco-socialists in dealing with the animal rights issue.

Anthropocentrism reserves moral consideration exclusively to human beings, judging our acts toward nature on the basis of how they affect us, not on how they affect other beings (Eckersley 1992). The values acknowledged to nature are instrumental in character, in the sense that the natural environment is only useful in as far as it provides resources that can be used to satisfy human wants, in both material and esthetic terms (Lundmark 2007).

To most anthropologists, the choice of the human side may seem self-evident, as they live with and learn from the local communities and internalize their values and viewpoints, "which may be the reason why anthropologists sometimes have difficulty communicating with environmentalists, compared with the relative success they have with the development community" (Einarsson 1993:82). As anthropologists seem generally predisposed to cultural relativism, the idea of 'going 
native' and accepting the indigenous populations' values (which, in many cases, happen to correspond with the dominant 'development' discourse) seems logical.

\section{Beyond anthropocentrism: indigenous environmentalism}

We may argue, however, that Western citizens grew up in the countries that lost most of the original forest long ago due to early agricultural developments. We would expect that their environmental values and attitudes will be low in comparison with indigenous communities who literally grew up in the jungle. The question remains why many of the indigenous populations seem to be anthropocentric.

Many socio-economic and political theories point to the power imbalances and imply that structurally weaker communities do not stand a chance against the dominant ideology of capitalism. Indeed, there is some evidence that the economically disadvantaged indigenous peoples do not have the luxury to afford the 'post-materialist' values, such as Western environmentalists presumably possess (Stevenson 2006). The utilitarian view of environment of the small-scale farmer, the slash-and-burn agriculturalist, the hunter and the fisher is perhaps not surprising due to their efforts to 'stay in the game' of the more powerful market forces and developers. However, in representing their interests, anthropologists forget about other members of communities they represent, the eco-centrics who aim to uphold the truly traditional values of interdependency and respect for nature.

The assumption that it is only the rich who can afford to worry about environment can be disputed by the fact that there are also many non-Western environmental activists in poor communities and that some communities and religions deny materialism and consumption (and implicitly Western 'values'). Criticizing Inglehart's theory of post-material values, Dunlap and Mertig (1997) demonstrated that there is little empirical evidence to show that the privileged social classes are more environmentalist than the poor. Higher levels of affluence do not necessarily increase pro-environmental attitudes in every society and that proenvironmental attitudes should not be thought of as being confined to only wealthy, industrialized nations (Dunlap and Mertig 1997; Dunlap and York 2008; Plombon 2011). Policy makers should embrace these findings: "Rather than pushing narrowly for economic growth and hoping that it will result in increased affluence and thus citizen concern for the environment, policies that recognize the inherent link between ecological and economic sustainability may prove more popular as well as efficacious" (Dunlap and York 2008:551).

While the privileged classes might claim to care more about environmental issues, their actual pattern of consumption demonstrates that there is a large gap between the people's knowledge of environmental problems and their motivation to behave toward their resolution (Kollmuss and Agyeman 2002). Following from this, increasing the level of material wealth will not automatically lead to more environmental protection. Examples of indigenous activists include the Kenyan Wangari Maathai who pioneered the Green Belt Movement (planting trees in Africa); the Nigerian Kenule "Ken" Saro Wiwa who was the President of the President, of the Movement for the Survival of the Ogoni People (leading campaign against environmental degradation of the land and 
waters of Ogoniland by the operations of the oil industry); Philippino's Gerardo Valeriano Ortega ("Doc Gerry") who fought against mining on the island of Palawan; and thousands of other indigenous activists who sacrificed their lives to the cause of fighting dams, mines, and other industrialist activities (e.g., http://www.radford. edu/wkovarik/envhist/murder.html).

In Loving Nature, a prominent environmental anthropologist Kay Milton (2002) analyzes the relationship between emotion and learning, and identifies sentimental commitment to conservation and 'personal understanding' of nature which is rooted in direct experiences of the non-human world and biophilia (Anderson 1996). Milton pointed out that anthropologists may be very helpful in answering questions like, "Why isn't everyone an environmentalist? Why do some people care more about the future of natural world than others do?" as these questions go to the heart of cultural diversity debate (Milton 2002:1). Environmental psychology draws on environmental ethics in an attempt to explain why certain individuals, who, for example, grew up in the same village next to the forest and witnessed its destruction, will gladly accept the job for the logging company clearing the remaining trees, while others will take on 'tree hugging.'

Developmental studies of people's environmental behaviors and attitudes shed some light upon this altruistic predisposition to nature by focusing on different social and psychological 'entry variables' (Hungerford and Volk 1990). The hypothesis that the early childhood encounters with nature are crucial for the development of positive environmental values is supported by retrospective reports of environmentalists, which are replete with stories of memorable encounters with pristine nature (Kahn and Kellert 2002; Korhonen and Lappalainen 2004; Louv 2005; Wells and Lekies 2006). Other formative experiences constitute experiences in organizations like the scouts or environmental groups, witnessing the destruction or pollution of a valued place, and reading books about nature and the environment (Chawla and Cushing 2007:440).

Anthropologists were traditionally dazzled by cultural diversity and did not necessarily address universal psychological variables in human behavior. Yet, there is evidence that despite culturally variable as well as economic, political, or religious orientation of the nations, there are groups of people or individuals that do take on environmental causes, while others do not. While the utilitarian attitude to nature seems common sense, as human survival and economic growth are dependent on energy and material resources that are extracted from natural ecosystems (Rees 1992). The so-called altruistic eco-orientation, or what Arno Naess (1973) defined as deep ecology perspective, is more difficult to explain. Perhaps, explanations for anthropocentric rather than eco-centric behavior need to be sought in theories exploring individual variables, such as the Lorax complex (Kopnina 2012).

'The Lorax complex' ${ }^{1}$ basically refers to the individuals upholding nonanthropocentric attitudes and altruistic 'love of nature' or biophilia. No matter

\footnotetext{
1 The Lorax is a creation of the children's writer Theodor Seuss Geisel (1904-1991), an American writer and cartoonist better known by his pen name, Dr. Seuss, who wrote a children's book about the Lorax, the prototype environmentalist fighting against the capitalist the Once-ler. The Lorax stands up for the 'Traffula trees' :"I am the Lorax, I speak for the trees.I speak for the trees, for the trees have no tongues...'.
} 
whether deep green environmentalists are Westerners or indigenous, their defense of non-human species is often overshadowed by economic, political, social interests. Isolation of deep green perspective is described in Rabindranath Tagore's story of Balai [(1928) 2009], the Indian boy who witnesses the 'weeds,' in all their beauty and diversity being removed from the garden:

Balai had long begun to realize that some of the pains he experienced were his alone. They were not felt by anyone around him. This boy really belonged to the age, millions of years ago, when the earth's would-be forests cried at birth among the marshlands newly sprung from the ocean's depth...... The plant, speechless foster mother of life on earth, has drawn nourishment from the heavens since time immemorial to feed her progeny; has gathered the sap, the vigour, the savour of life for the earth's immortal store; and raised to the sky the message of beleaguered life, 'I want to stay.' Balai could here that eternal message of life in a special way in his bloodstream. We used to laugh at this a good deal [Tagore (1928) 2009:257].

\section{Toward conservationist anthropology}

It may be also argued that most people-or perhaps members of all species-are 'naturally' centered upon themselves. It is also not surprising that the discipline of anthropology is per definition anthropocentric.

Anthropologists commonly define their discipline, anthropology, as the study of anthropos (humankind) and think it perfectly natural to pay little or no attention to the nonhuman realm of animalkind. Of course, animals do figure in anthropological studies but they do so mainly as raw material for human acts and human thought (Noske 1989).

However, in the tradition of anthropological moral engagement with the 'underdog,' the author wants to raise an ethical issue that interests of the most vulnerable 'community,' that of non-human species, should be considered. As the fictional characters of the Lorax or Balai, conservationists are often met with hostility of the communities, governments, and anthropologists. While concerns with issues of egalitarian distribution of natural resources, power, environmental justice, and the like are certainly salient, there is a need for explicitly conservational anthropology that does not subordinate conservation (in both moral/ethical and practical terms) to the exclusive interests of the people but sees conservation AND people as one. In fact, we as humanity can probably learn from non-Western traditions that represented continuous relationship between people and nature (Rowe 1994).

First, it is necessary to realize that environmental destruction and the process of its repair happen at all levels_-both those of industrial elites and local communities. Because of the power imbalances that make many communities feel like the 'losers of globalization' (Bodley 2008), and population growth with increasing need for more resources, 'traditional practices' these days are often intertwined with 
capitalist economy. Even though the practices, such as forest clearing for agriculture, are small in scale, they might affect the very survival of certain species that are already endangered. Anthropologists seem to place economic rights and cultural survival of people above concerns about physical survival of nonhuman species. Helpfully, increasing numbers of anthropologists finds themselves reconciling human and ecological interests. Bodley (2008), for example, critically deals with conventional development strategies and 'corporate capitalism' and exhibits strong eco-centric tendencies while still being sensitive to the basic needs of indigenous peoples and peasants.

The second necessity is to realize that eco-centric people-indigenous or not-are not 'against' people, but rather see human beings as part of the eco-system. Brosius (2006) noted that anthropology is more interested in identifying what is wrong with conservation than in trying to make things better. The importance of people in successful conservation is undeniable, as Kent Redford of Wildlife Conservation Society notes in the forum, "Misreading the Conservation Landscape," addressing the current state of conversations between conservationists and social scientists.

Conservation is practised by people with a mixture of ethical positions. It is fair to characterize much of conservation, at least in the developed world, as being firmly rooted in a biocentric position. We often see humans as threats to the biological systems we champion. Whereas it is true that the current dismal state of the biosphere is due in large part to accumulated human impact, it is equally true that any success in altering this will require human action. We have been chastised by social scientists for talking about humans only as threats - a persuasive admonition that has contributed to a gradual move towards viewing humans as legitimate elements in nature and an explicit part of the solutions to conservation problems (Redford 2011:325).

Redford then states that social scientists as well as conservationists often misunderstand each other, as conservationists sometimes fail to acknowledge that people are not 'enemies,' and that social scientists fail to consider interests of other species. Redford urges social scientists and conservationists to work together:

Researchers are working on institutional ethnographies and placing social scientists in the workplace of conservation organizations. We need this work. We need to learn of, and from, our mistakes. We must improve our practice. For this, I maintain, we need the help—and informed criticism-of our social scientist colleagues (Ibid, p. 329).

Conservationists need to understand better how to communicate with anthropologists and other social scientists and to include humans-particularly communities living next to wildlife preserves - into solution-seeking process. Anthropologists, on the other hand, need to recognize the uniqueness of eco-centric perspective in being truly universal. Eco-centric perspective does not include humans from the biosphere but does call for inclusion of the 'voice' of other biospherical citizens (Eckersley 1995, 2004). The importance of the dialogue between individuals holding different gradations of biocentric and anthropocentric values is certainly not limited to conservationists and anthropologists, but also includes all communities and 
individuals that traditionally_and presently_-strongly care about the environment_-including humans.

\section{Conclusion}

In this article, it has been asserted that while most anthropologists are not explicitly 'choosing sides' in the conservation/culture conflict, anthropological focus on the indigenous groups is often pitched against the conservationist efforts to institute limits to 'cultural practices' that negatively affect non-human species. Anthropologists have accused conservationists of eco-imperialism and the imposition of their own vision of environmental values and the implicit attempt to dispossess local communities of their land, natural resources, and other benefits of modern industrial development. The author has argued that the view of conservationists as neo-imperialist is ironic in light of the fact that the very notions that anti-conservationists are supporting, those of 'human rights' and 'development,' are arguably impositions of industrial and political elites. Ecocentrism, and not anthropocentrism espoused by the mainstream development discourse, may in fact have been embedded in traditional societies, and environmental movement appears to be universal, rather than restricted to Western post-materialists. The anthropocentric position espoused by pro-development anthropologists is reflected in the work of constructivist anthropologists who argue that wilderness can only be perceived through the eyes of the humans, implicitly devaluing non-human species to social constructions.

The realization of anthropocentric bias warrants a new type of environmentally conscious and morally engaged conservationist anthropology. Conservationist anthropologists align themselves with environmental sociology in acknowledging anthropocentric bias in their discipline. Conservationist anthropologists recognize that 'natural resources' or 'ecosystem services' are not unlimited and, more saliently, that non-human species have intrinsic value. In this context, it was argued that proliferation of 'traditional practices,' tainted by global capitalism, might not be as innocent as they used to be in pre-industrial age.

Conservationist focus in anthropology presents a number of moral and practical challenges. One of the challenges is that it is not always possible to satisfy the interests of both the economically disadvantaged and those who are being 'distributed' or 'consumed' as part of the expanding economic pie. Anthropological engagement would mean working together and not against conservationists to ensure that all creatures on this planet, including humans, can share a beautiful future.

Open Access This article is distributed under the terms of the Creative Commons Attribution License

which permits any use, distribution, and reproduction in any medium, provided the original author(s) and the source are credited.

\section{References}

Alcorn, J.B. 2008. Beauty and the Beast-Human Rights and Biocultural Diversity, Resurgence Magazine, On-line http://www.garfieldfoundation.org/resources/Beauty\%20\&\%20The\%20Beast.pdf. 
Allendorf, K. 2007. Residents' attitudes toward three protected areas in Southwestern Nepal. Biodiversity and Conservation 16: 2087-2102.

Allendorf, T., K.K. Swe, T. Oo, Y. Htut, M. Aung, K. Allendorf, L.-A. Hayek, P. Leimgruber, and C. Wemmer. 2006. Community attitudes toward three protected areas in upper Myanmar (Burma). Environmental Conservation 33: 344-352.

Anderson, E.N. 1996. Ecologies of the heart. Oxford: Oxford University Press.

Barua, M. 2010. Whose issue? Representations of human-elephant conflict in Indian and international media. Science Communication 32(1): 55-75.

Biersack, A. 1999. Introduction: From the "new ecology" to the new ecologies. American Anthropologist 101(1): 5-18.

Black, C. 2010. Schooling the world: The White Man's last burden'. Documentary film. Lost People Films. http://www.schoolingtheworld.org.

Blaser, M., H. A. Feit, G. McRae, eds. 2004. In the way of development: Indigenous peoples, life projects and globalization. London: Zed Books and Ottawa: International Development Research Centre.

Blok, A. 2010. War of the Whales: Post-Sovereign Science and Agonistic Cosmopolitics in JapaneseGlobal Whaling Assemblages. In, Science technology human values, 36: 55. Online at: http://sth.sagepub.com/content/36/1/55.

Bodley, J.H. 2008. Anthropology and contemporary human problems, 5th ed. Lanham, MD: AltaMira Press.

Braun, B. 2008. Environmental issues: Inventive life. Progress in Human Geography 32(5): 667-679.

Brockington, D. 2002. Fortress conservation: The preservation of the Mkomazi Game Reserve, Tanzania. Bloomington, IN: Indiana University Press.

Brosius, J.P. 1997. Endangered forest, endangered people: Environmentalist representations of indigenous knowledge. Human Ecology 25: 47-69.

Brosius, J.P. 1999. Green dots, pink hearts: Displacing politics from the Malaysian Rainforest. American Anthropologist 101(1): 36-57.

Brosius, J.P. 2006. Common ground between anthropology and conservation biology. Conservation Biology 20: 683-685.

Caldwell, L.K. 1990. Between two worlds: Science, the environmental movement and policy choice. New York, NY: Cambridge University Press.

Callon, M. 1986. Some elements of a sociology of translation: Domestication of the scallops and the fishermen of St. Brieuc Bay. In Power, action, belief: A new sociology of knowledge. J. Law (Ed.), 196-233. London: Routledge and Kegan Paul.

Castree, N. 2003. Environmental issues: Relational ontologies and hybrid politics. Progress in Human Geography 27(2): 203-211.

Catton, W., and R. Dunlap. 1978a. Environmental sociology: A new paradigm. The American Sociologist 13: 41-49.

Catton, W., and R. Dunlap. 1978b. Paradigms, theories, and the primacy of the HEP/NEP distinction. The American Sociologist 13: 256-259.

Catton, W., and R. Dunlap. 1980. A new ecological paradigm for post-exhuberant Sociology. American behavioral scientist 24: 15-47.

Chawla, L., and D. Cushing. 2007. Education for strategic environmental behaviour. Environmental Education Research 13(4): 437-452.

Chernela, J. 2001. Fractured lands: The politics of conservation in North-Central Brazil Entrecaminos 6: $27-40$.

Chokor, B.A. 1993. Government policy and environmental protection in the developing world: The example of Nigeria. Environmental Management 17(1): 15-30.

Cronon, W. 1996. The trouble with wilderness, or getting back to the wrong nature. In Uncommon ground: Rethinking human place in nature, ed. W. Cronon, 69-90. New York, NY: W. W. Norton and Co.

DesJardins, J.R. 2005. Invitation to environmental philosophy. New York: Thomson.

Desmond, J. 2011. Requium for Roadkill: Death and Denial On America's Roads. Paper presented at the American Anthropological Association Meeting in Montreal, Canada on Wednesday, November 16, 2011.

Diamond, J. M. 1987. The Worst Mistake In The History Of The Human Race, Discover, 64-66. http://virtual.yosemite.cc.ca.us/ottej/PDF/diamond.pdf

Dunlap, R., and W. Catton. 1979. Environmental sociology. Annual Review of Sociology 5: 243-273. 
Dunlap, R., and W. Catton. 1983. What environmental sociologists have in common (Whether concerned with 'built' or 'natural' environments). Sociological inquiry 53: 113-135.

Dunlap, R., and W. Catton. 1994. Struggling with human exemptionalism: The rise, decline and revitalization of environmental sociology. The American Sociologist 25: 5-30.

Dunlap, R.E., and A.G. Mertig. 1997. Global environmental concern: An anomaly for postmaterialism. Social Science Quarterly 78(1): 24-29.

Dunlap, R.E., and R. York. 2008. The globalization of environmental concern and the limits of the postmaterialist values explanation: Evidence from four multinational surveys. The Sociological Quarterly 49: 529-563.

Eckersley, R. 1992. Environmentalism and political theory: Toward an ecocentric approach. New York, NY: State University of New York Press.

Eckersley, R. 1995. Liberal democracy and the rights of nature: The struggle for inclusion. Environmental Politics 4(4): 169-198.

Eckersley, R. 2004. The green state: Rethinking democracy and sovereignty. London: MIT Press.

Einarsson, N. 1993. All animals are equal but some are cetaceans: Conservation and culture conflict. In Environmentalism: The view from anthropology, ed. Kay Milton, 73-84. New York: Routledge.

Ellen, R. 1993. Rhetoric, practice, and incentive in the face of changing times: A case study of Nuaulu attitudes to conservation and deforestation. In Environmentalism: The view from anthropology, ed. K. Milton. London: Routledge.

Ellen, R. 2008. Forest Knowledge, Forest Transformation: Political Contingency, Historical Ecology, and the Renegotiation of Nature in Central Seram. In Environmental anthropology: A historical reader, eds. M. Dove \& C. Carpenter. Blackwell Anthologies in Social and Cultural Anthropology. Oxford: Blackwell.

Escobar, A. 1996. Constructing nature: Elements for a poststructural political ecology. In Liberation ecologies: Environment, development, social movements, ed. R. Peet, and M. Watts, 46-68. London: Routledge.

Ferry, L. 1995. The new ecological order. Chicago, IL: University of Chicago Press.

Foster, J. B. 2011. A keynote speech at the Climate Change/Social Change conference sponsored by the Socialist Alliance, Melbourne 30 September-3 October. http://environment-ecology.com/symposiumsconferences/427-world-at-a-crossroads-climate-change-social-change-conference-ii.html.

Foster, J.B., B. Clark, and R. York. 2010. The ecological rift: Capitalism's war on the earth. New York, NY: Monthly Review Press.

Gadgil, M. 1993. Indigenous knowledge for biodiversity conservation. Ambio 22(2-3): 156.

Goedeke, T.L., and S. Rikoon. 2008. Otters as actors: Scientific controversy, dynamism of networks, and the implications of power in ecological restoration. In Social Studies of Science 38(1): 111-132.

Gururani, S. 1995. "The forests are forever!" The politics of conservation and use in Central Himalayas, India. Culture, Agriculture, Food and Environment 16: 13-18.

Gururani, S. 2000. Regimes of Control, Strategies of Access: Politics of Forest Use in The Uttarakhand Himalaya, India. In Agrarian environments: resources, representations, and rule in India, (eds) A. Agrawal \& K. Sivaramakrishnan. Durham, NC: Duke University Press.

Grundy, W. G. 1995. Solar cookers and social classes in Southern Africa. Techné: Journal of Technology Studies, Gray Norton, ed. V: 3-7.

Haenn, N. 2011. Who's got the money now?: Re-examining the conservation economy. In Environmental anthropology today, ed. H. Kopnina, and E. Shoreman-Ouimet. New York and Oxford: Routledge.

Hartmann, I. 2011. http://independent.academia.edu/IngridHartmann/Papers.

Healy, S. 2007. Deadly dingoes: 'Wild' or simply requiring 'due process'? In Social Studies of Science 37(3): 443-471.

Hinchliffe, S., and S. Whatmore. 2006. Living cities: Towards a politics of conviviality. Special 'Technonatures' issue of Science as Culture 15(3): 123-138.

Horowitz, L.S. 2010. "Twenty years is yesterday": Science, multinational mining, and the political ecology of trust in New Caledonia. Geoforum 41(4): 617-626.

Hughes, D.M. 2005. Third nature: Making space and time in the Great Limpopo conservation area. Cultural Anthropology 20(2): 157-184.

Hungerford, H., and T. Volk. 1990. Changing learner behavior through environmental education. Journal of Environmental Education 21(3): 8-21.

Igoe, J. 2004. Conservation and globalization: A study of national parks and indigenous communities from East Africa to South Dakota. Belmont, CA: Wadsworth. 
Infield, M. 1988a. Attitudes of a rural community towards conservation and a local conservation area in Natal, South Africa. Biological Conservation 45: 21-46.

Infield, M., and A. Namara. 2001. Community attitudes and behaviour towards conservation: An assessment of a community conservation programme around Lake Mburo National Park, Uganda. Oryx 35: 48-60.

Infield, M. 1988b. 'Attitudes of a rural community towards conservation and a local conservation area in Natal. South Africa' Biological Conservation 45: 21-46.

Ingold, T. 2008. Bindings against boundaries: Entanglements of life in an open world. Environment and Planning A 40(8): 1796-1810.

Kahn Jr., P. H., and S.R. Kellert (eds.). 2002. Children and nature: Psychological, sociocultural, and evolutionary investigations. Cambridge MA: MIT Press.

Kang, Y. 2003. Review: Translating nature and claim-makings in Southeast Asia. Anthropological Inquiry 76(2): 335-341.

Kidner, D.W. 2000. A critique of the social construction of nature. In From nature to natures: Contestation and reconstruction, ed. D. Inglis, J. Bone, and R. Wilkie, 263-281. London: Routledge.

Kohn, E. 2007. How dogs dream: Amazonian natures and the politics of transspecies Engagement. In American ethnologist 34(1): 3-24.

Kollmuss, A., and J. Agyeman. 2002. Mind the gap: Why do people act environmentally and what are the barriers to pro-environmental behavior? Environmental Education Research 8(3): 239-260.

Kopnina, H. 2012. Revisiting education for sustainable development (ESD): Examining anthropocentric bias through the transition of environmental education to ESD. In Sustainable development. Early View: http://onlinelibrary.wiley.com/doi/10.1002/sd.529/abstract.

Kopnina, H., and H. Keune. 2010. Health and environment: Social science perspectives. New York: Nova Science Publishers, Inc.

Kopnina, H., and E. Shoreman-Ouimet. 2011. Environmental anthropology today. New York, Oxford: Routledge.

Korhonen, K., and A. Lappalainen. 2004. Examining the environmental awareness of children and adolescents in the Ranomafana region, Madagascar. Environmental Education Research 10(2): 195-216.

Kottak, C.P. 1999. The new ecological anthropology. In American Anthropologist 101(1): 35.

Latour, B. 1988. The pasteurization of France. Cambridge: Harvard University Press.

Law, J. 1986. On the methods of long-distance control: Vessels, navigation, and the Portuguese route to India. In Power, action and belief: A new sociology of knowledge?, ed. J. Law, 234-263. London: Routledge and Kegan Paul.

Lewis, D. 2005. Anthropology and development: the uneasy relationship. In A handbook of economic anthropology, ed. Carrier, James G., 472-486. Edward Elgar, Cheltenham, UK. http://eprints.lse.ac. uk/253/.

Lewis, D., and D. Mosse. 2006. Encountering order and disjuncture: Contemporary anthropological perspectives on the organisation of development. Oxford Development Studies 34(1): 1-14.

Lidskog, R., and I. Elander. 2009. Addressing climate change democratically. Multi-level governance, transnational networks and governmental structures. Sustainable Development 18(1): 32-41.

Louv, R. 2005. Last child in the woods: Saving our children from nature-deficit disorder. North Carolina: Algonquin Books of Chapel Hill.

Lowe, C. 2005. Wild profusion: Biodiversity conservation in an Indonesian Archipelago. Princeton, NJ: Princeton University Press.

Lundmark, C. 2007. The new ecological paradigm revisited: anchoring the NEP scale in environmental ethics. Environmental Education Research, 13(3): 329-347.

McElroy, A. (2013). Sedna's children: Inuit elders' perceptions of climate change and food security. In Future Trends in environmental anthropology, Eds. H. Kopnina and E. Shoreman-Ouimet. New York and Oxford: Routledge (Forthcoming).

McGregor, J. 2005. Crocodile crimes: people versus wildlife and the politics of postcolonial conservation on Lake Kariba, Zimbabwe. Geoforum 36(3): 353-369.

Mead, M. 1977. Applied Anthropology: The State of the Art. In Perspectives on Anthropology, 1976. Washington, DC: American Anthropological Association.

Milton, K. 2002. Loving nature: Toward an ecology of emotion. NewYork, NY: Routledge.

Mosse, D. 2005. Cultivating development: An ethnography of aid policy and practice. London; Ann Arbor, MI: Pluto Press. 
Muller-Böker, U. 2000. Livelihood strategies and local perceptions of a new nature conservation project in Nepal-The Kanchenjunga conservation area project. Mountain Research and Development 20: 314-331.

Naess, A. 1973. The shallow and the deep: Long-range ecology movement: A summary. Inquiry 16: 95-99.

Nelson, F. 2012. Community rights, conservation and contested land. The politics of natural resource governance in Africa. New York, NY: Routledge.

Netting, R.M. 1993. Smallholders, householders: Farm families and the ecology of intensive, sustainable agriculture. Stanford: Stanford University Press.

Neumann, R.P. 1998. Imposing wilderness: Struggles over livelihood and nature preservation in Africa. Berkeley: University of California Press.

Newmark, W.D., N.L. Leonard, H.I. Sariko, and D.-G.M. Gamassa. 1993. Conservation attitudes of local people living adjacent to five protected areas in Tanzania. Biological Conservation 63: 177-183.

Noske, B. 1989. Humans and other animals: Beyond the boundaries of anthropology. London: Pluto Press.

Novellino, D. 2003. Contrasting Landscapes, Conflicting ontologies: Assessing environmental conservation on Palawan Island (The Philippines). In Ethnographies of conservation: Environmentalism and The distribution of privilege, (eds) D.G. Anderson \& E. Berglund. Oxford: Berghahn.

Novellino, D. 2009. The role of "hybrid" NGOs in the conservation and development of Palawan Island, The Philippines. Society and Natural Resources 23: 165-180.

Orlove, B.S., and S.B. Brush. 1996. Anthropology and conservation of biodiversity. Annual Review of Anthropology 25: 329-352.

Parkes, P. 2000. Enclaved knowledge: Indigent and indignant representations of environmental management and development among the Kalasha of Pakistan. In Indigenous environmental knowledge and its transformations: Critical anthropological perspectives, eds. R. Ellen, P. Parkes \& A. Bicker, 253-291. New York: Harwood Academic.

Pearce, F. 2012. Busting the forest myths: People as part of the solution. Yale environment 360, Yale School of Forestry and Environmental Studies. http://e360.yale.edu/feature/busting_the_forest_ myths_people_as_part_of_the_solution.

Plombon, E. 2011. Factors affecting pro-environmental attitudes. UW-L Journal of Undergraduate Research XIV. http://www.uwlax.edu/urc/JUR-online/PDF/2011/plombon.SOC.pdf.

Posey, D.A., and M.J. Balick (eds.). 2006. Human impacts on Amazonia: The role of traditional ecological knowledge in conservation and development. New York, NY: Columbia University Press.

Rees, W. 1992. Understanding Sustainable Development. In Sustainable development and the future of cities, Eds. B. Hamm, G. Zimmer and S. Kratz. Proceedings of an international summer seminar, Bauhaus Dessau, 7-14 September 1991, 17-40.

Regan, T. 1984. The case for animal rights. London: Routledge.

Raffles, H. 2002. In Amazonia: A natural history. Princeton, NJ: Princeton University Press.

Redford, K. 2011. "Misreading the conservation landscape." Oryx: the International Journal of Conservation: http://journals.cambridge.org/action/displayIssue?jid=ORX\&tab=currentissue.

Rowe, S.J. (1994). Ecocentrism: The chord that harmonizes humans and earth. The Trumpeter 11(2): $106-107$.

Shiva, V. 1993. Monocultures of the mind: Biodiversity, biotechnology and agriculture. New Delhi: Zed Press.

Shoreman-Quimet, E., and H. Kopnina. 2011. Introduction: Environmental anthropology yesterday and today. In Environmental anthropology today, ed. H. Kopnina, and E. Shoreman-Ouimet. New York and Oxford: Routledge.

Sikor, T., and J. Stahl (eds.). 2011. Forests and people: Property, governance and human rights. London: Earthscan.

Singer, P. 1975. Animal liberation. New York: Random.

Smith, N. 1996. The production of nature. In Future natural, ed. George Robertson, and Melinda Marsh, 35-54. London: Routledge.

Sobel, D. 1996. Beyond ecophobia: Reclaiming the heart in nature education. Great Barrington, MA: Orion Society.

Spring, J. 2004. How educational ideologies are shaping global society: Intergovernmental organizations, NGO's, and the decline of the state. Mahwah, NJ: Laurence Erlbaum Associates.

Stevenson, R. 2006. Tensions and transitions in policy discourse: Recontextualising a decontextualised EE/ESD debate. Environmental Education Research 12(3-4): 277-290. 
Tagore, R. [1928] 2009. 'Balai’ from selected short stories of Rabindranath Tagore, 256-257. Oxford University press.

Taylor, P. 1986. Respect for nature. A theory of environmental ethics. Princeton, NJ: Princeton University Press.

Theodossopoulos, D. 1997. Turtles, farmers and ecologists: The cultural reasons behind a community's resistance to environmental conservation. Journal of Mediterranean Studies 7(2): 250-267.

Theodossopoulos, D. 2002. Environmental conservation and indigenous culture in a Greek Island community. In Conservation and mobile indigenous peoples: Displacement, forced settlement and sustainable development, ed. D. Chatty, and M. Colchester. Oxford: Berghahn.

Thompson, C. 2002. When elephants stand for competing philosophies of nature: Amboseli National park, Kenya. In Complexities: Social studies of knowledge practices, 166-190. Durham, NC: Duke University Press.

Thorne, L. 1998. Kangaroos: The non-issue. Society and Animals 6: 167-182.

Turner, T. 1993. The role of indigenous peoples in the environmental crisis: The example of the Kayapó of the Brazilian Amazon. Perspectives in Biology and Medicine 36(3): 526-547.

Trusty, T. 2011. From ecosystem services to unfulfilled expectations: Factors influencing attitudes toward the Madidi protected area. In Environmental anthropology today, ed. H. Kopnina, and E. ShoremanOuimet. New York and Oxford: Routledge.

Tsing, A.L. 1999. Becoming a tribal elder, and other green development fantasies. In Transforming Indonesian Uplands: Marginality, Power and Production, ed. T.M. Li, 159-202. OPA, Netherlands: Harwood Academic Publishers.

Wagley, C. 1976. [1953] Amazon town. New York: Oxford University Press.

Walker, D., J.P. Jones, S. Roberts, and O. Frohling. 2007. When participation meets empowerment: The WWF and the politics of invitation in the Chimalapas, Mexico. Annals of the Association of American Geographers 97(2): 423-444.

Walley, C.J. 2002. They scorn us because we are uneducated: Knowledge and power in a Tanzanian Marine Park. Ethnography 3(3): 265-298.

Walley, C. 2004. Rough waters: Nature and development in an East African Marine Park. Princeton, NJ: Princeton University Press.

Whatmore, S., and S. Hinchliffe. 2010. Ecological landscapes. In Oxford handbook of material culture studies, ed. D. Hicks, and M. Beaudry, 439-454. Oxford: OUP.

Wells, N. and K. Lekies 2006. Nature and the life course, Children, Youth and Environments, 16(1):1-24. Available online at: http://www.colorado.edu/journals/cye (accessed February 2012).

Wenzel, G. 1991. Animal rights, human rights: Ecology, economy and ideology in Canadian Arctic. London: Belhaven Press.

West, P. 2005. Translation, value and space: Theorizing an ethnographic and engaged environmental anthropology. American Anthropologist 107: 632-642.

West, P. 2006. Conservation is our government now. The politics of ecology in Papua New Guinea. Durham, NC: Duke University Press.

Whatmore, S. 2002. Hybrid geographies: Natures cultures spaces. London: Sage.

Whatmore, S., and L. Thorne. 1998. Wild(er)ness: Reconfiguring the geographies of wildlife. In Transactions of the Institute of British Geographers 23(4): 435-454.

Yussof, K. 2011. Aesthetics of loss: Biodiversity, banal violence and biotic subjects. In Transitions of the institute of British Geographers. Early view: http://onlinelibrary.wiley.com/doi/10.1111/j.14755661.2011.00486.x/abstract.

Zerner, C. 2000. Toward a broader vision of justice and nature conservation. In People, plants and justice: The politics of nature conservation, ed. C. Zerner. New York, NY: Columbia University Press.

Zerner, C. 2003. Moving translations: Poetics, performance, and property in Indonesia and Malaysia. In Culture and the question of rights: Forests, coasts and seas in Southeast Asia, ed. C. Zerner, 1-23. Durham, NC: Duke University Press. 